\title{
Analysis for genotyping Duffy blood group in inhabitants of Sudan, the Fourth Cataract of the Nile
}

\author{
Agnieszka Kempińska-Podhorodecka ${ }^{1 *}$, Oktawian Knap $^{2}$, Arleta Drozd $^{3}$, Mariusz Kaczmarczyk ${ }^{4}$, Miroslaw Parafiniuk ${ }^{5}$, \\ Milosz Parczewski ${ }^{6}$ and Andrzej Ciechanowicz ${ }^{4}$
}

\begin{abstract}
Background: Genetic polymophisms of the Duffy antigen receptor for the chemokines (DARC) gene successfully protected against blood stage infection by Plasmodium vivax infection. The Fy (a-, b-) phenotype is predominant among African populations, particularly those originating from West Africa, and it is rare among non-African populations. The aim of this study was to analyse the frequency of four Duffy blood groups based on SNPs (T-33C, G125A, G298A and (5411T) in two local tribes of Sudanese Arabs, the Shagia and Manasir, which are both from the region of the Fourth Nile cataract in Sudan.
\end{abstract}

Methods: An analysis of polymorphisms was performed on 217 individuals (126 representatives of the Shagia tribe and 91 of the Manasir). Real-time PCR and TaqMan Genotyping Assays were used to study the prevalence of alleles and genotypes.

Results: The analysis of allelic and genotype frequency in the T-33C polymorphisms demonstrated a significant dominance of the $C$ allele and CC genotype ( $O R=0.53$ [0.32-0.88]; $p=0.02$ ) in both tribes. The G125A polymorphism is associated with phenotype Fy(a-, b-) and was identified in $83 \%$ of Shagia and $77 \%$ of Manasir. With regard to G298A polymorphisms, the genotype frequencies were different between the tribes $(p=0,002)$ and no single $A A$ homozygote was found. Based on four SNPs examined, 20 combinations of genotypes for the Shagia and Manasir tribes were determined. The genotype CC/AA/GG/CT occurred most often in Shagia tribe (45.9\%) but was rare in the Manasir tribe (6.6\%) ( $p<0.001$ Shagia versus Manasir). The $F Y^{*} A^{E S}$ allele was identified in both analysed tribes. The presence of individuals with the $F Y^{*} A F Y^{*} A$ genotype was demonstrated only in the Shagia tribe.

Conclusion: This is probably the first report showing genotypically Duffy-negative people who carry both $F Y^{*} B^{E S}$ and $F Y^{*} A^{E S}$. The identification of the $F Y^{*} A^{E S}$ allele in both tribes may be due to admixture of the non-African genetic background. Taken as a whole, allele and genotype frequencies between the Shagia and the Manasir were statistically different. However, the presence of individuals with the $F Y^{*} A F Y^{*} A$ genotype was demonstrated only in the Shagia tribe.

Keywords: Duffy blood group, Malaria, Sudanese Arabs, Shagia, Manasir, SNP polymorphism, Real-Time PCR

\section{Background}

Africa is considered as the origin of modern humans and is one of the most ethnically and genetically diverse regions of the world [1]. The African populations were shaped by demographic forces that influence variation on

\footnotetext{
* Correspondence: agnieszkakempinska@interia.eu

${ }^{1}$ Medical Biology Laboratory, Pomeranian Medical University, Powstancow Wlkp 72, 70-111 Szczecin, Poland

Full list of author information is available at the end of the article
}

a genome-wide scale, such as ancient migration events and fluctuations in population size, and by evolutionary forces that influence individual loci, such as natural selection and mutation [2]. A great impact on human evolution is associated with malaria, one of the most significant infectious diseases in the world [3]. Selection pressure by this pathogen on the human genome occurred at least 10,000 years ago. It has been generally recognized that malaria was one of the factors determining population
C Biomed Central

() 2012 Kempińska-Podhorodecka et al; licensee BioMed Central Ltd. This is an Open Access article distributed under the terms of the Creative Commons Attribution License (http://creativecommons.org/licenses/by/2.0), which permits unrestricted use, distribution, and reproduction in any medium, provided the original work is properly cited. 
increases in the incidence of atypical variants of haemoglobin, such as haemoglobin S (HbS), C (HBC) or E (HBE), as well as variability in the Duffy blood group system.

The Duffy antigen is located on the surface of red blood cells. Duffy antigens are coded on the Duffy antigen receptor for the chemokine gene (DARC), located on the long arm of chromosome 1 (1.q22-1.q23) [4]. The protein encoded by this gene is a glycosylated membrane protein, which is a non-specific receptor for several chemokines and can be utilized by human malarial parasites Plasmodium vivax and Plasmodium knowlesi in order to invade erythrocytes.

Genetic polymorphisms were identified in humans, which affect the expression of the Duffy antigen. Duffy antigen is present in two major allelic forms, differing in an amino acid at position 42 in coding sequence (G125A) (i.e. glycine in $F Y^{*} A$ and aspartic acid in $F Y^{*} B$ ) [5-9] and point mutation at position $\mathrm{T}-33^{\circ} \mathrm{C}$ (previously described as $\mathrm{T}-46^{\circ} \mathrm{C}$ ) in GATA box responsible for the $F Y^{*} A^{E S}$ ( $E S$ = erythrocyte silent) and the $F Y^{*} B^{E S}$ alleles (common African allele) [3,10-16]. These four alleles: $F Y^{*} A, F Y^{*} B$, $F Y^{*} A^{E S}$ and $F Y^{*} B^{E S}$ contribute to a total of ten genotypes: $F Y^{*} A / F Y^{*} A, F Y^{*} A / F Y^{*} B, F Y^{*} A / F Y^{*} A^{E S}, F Y^{*} A / F Y^{*} B^{E S}$, $F Y^{*} B / F Y^{*} B, F Y^{* *} B / F Y^{*} A^{E S}, F Y^{*} B / F Y^{*} B^{E S}, F Y^{*} A^{E S} / F Y^{*} A^{E S}$, $F Y^{*} A^{E S} / F Y^{*} B^{E S}, F Y^{*} B^{E S} / F Y^{*} B^{E S}[17,18]$. The last three genotypes of those above-mentioned are responsible for the phenotype Fy(a-, b-) which is responsible for resistance to malaria. This phenotype is predominant among African people, especially those originating in West Africa and it is rare among non-African populations [11]. This lack of DARC receptors among almost all individuals of West African origin has been suggested as a natural selection induced by $P$. vivax [19]. Moreover, a less common variation of the allele $F Y^{*} X$, associated with weak expression of $F y^{b}$ antigen was also identified $[8,10,20]$.

Due to the characteristic distribution of DARC alleles: $F Y^{*} A^{E S}$ and $F Y^{*} B^{E S}$, they have been used to assess admixture and ethnic backgrounds of populations like Saudi Arabs [21], Israeli Jews [22,23], Grande Comore Island islanders (Njazidja) [24] and also some African descent populations [25]. Characterizing the pattern of genetic variation among ethnically diverse African populations is critical for reconstructing human evolutionary history, clarifying the population history of Africans and AfricanAmericans and determining the proper design and interpretation of genetic disease association studies $[26,27]$.

Genetic variation of many populations across Africa is enigmatic [28]. There are some very uncommon and unique African tribes that are not well genetically characterized. Current demographic and political situations in Africa make any anthropological research conducted in this area very valuable. The Shagia tribe, until recently, inhabited the area from the Kurti to the Fourth Cataract. This tribe led an agricultural lifestyle and was regarded as morally and culturally governed by the Sudanese Arabs. The village populations were not numerous (4060 persons per village) and were located at small distances from each other in difficult to access areas. Residents were isolated geographically and culturally, which led to genetic isolation. Recently, the natural residence of this tribe has been changed due to the construction of dams in the Merowe at the height of the Fourth Cataract of the Nile river (Sudan), which required massive displacement and dispersion of the Shagia tribe. For that reason the presented study is exclusive and irreplaceable. The second tribe examined, the Manasir, lives approximately $80 \mathrm{~km}$ from the described Shagia villages and represents a population with admixture of other populations. Approximately 50,000-78,000 people (including the ethnically related Shagia and Manasir tribes) have been displaced to the settlements built in the Nubian Desert. Despite the undoubted benefits of the construction of new hydroelectric plants, such as universal access to electricity, there are far-reaching consequences for the environment and human health (e.g., the development of diseases, such as Snail fever).

The purpose of this study was to analyse the genetic structure of the Shagia and Manasir tribes using the variability of the single nucleotide polymorphisms in Duffy gene, such as two typical for African populations SNPs: T-33 C [5,29] and G125A [14,30], along with two other SNPs: G298A [31-33] and C5411T.

The distinction of the Shagia tribe is one of the reasons why the prevalence of gene polymorphisms in the FY (Duffy) is very interesting. The results obtained in this study, based on the biological samples collected before the tribe dislocation, may be helpful in determining the origin of this tribe and enriching the existing knowledge on population movements in the African continent.

\section{Methods}

\section{Subjects}

An analysis of polymorphisms was performed on 217 individuals (101 females and 116 males; median age 30 years). Genetic material (buccal swabs) was collected from 126 individuals of the Shagia tribe and from 91 representatives of the Manasir that consented to participate in the study. Both tribes inhabited the Fourth Cataract of the Nile at the time of the study.

The authors state their research conforms to the Helsinki Declaration and to local legislation. Informed consent from patients was a prerequisite. Institutional ethical clearance from the Ethic Committee of Pomeranian Medical University was obtained. 


\section{Genotyping}

Buccal swabs for subsequent DNA extraction were collected from all individuals that consented to participate in the study. Collected swabs were carefully dried in a separate area in order to avoid contamination. For DNA extraction, a BuccalAmp DNA Extraction Kit (Epicentre, Madison, USA) was used. Oligonucleotide primers and TaqMan probes for Duffy polymorphisms (i.e. Rs2814778, Rs12075, Rs13962 and Rs863002) were designed and synthesized by Applied Biosystems (ID: C_15769614_10, C_2493442_10, C_2493443_10, C_7480790_10, respectively). The fluorescence data were analysed with allelic discrimination 7500 Software, v.2.0.2.

\section{Statistical analysis}

Statistical analyses were performed with the StatView ${ }^{\circledR}$ program using the chi ${ }^{2}$ Pearsons, Fisher test. Haplotype analysis using haplo.stats [34] package was made by $R$ software, version 2.10.1. The validation of haplotypes and a linkage disequilibrium (LD) block of polymorphisms were performed using Haploview, version 4.02. $P<00.05$ was considered statistically significant.

\section{Results}

The identification of genes encoding the blood group antigens, such as DARC, has been used for many years to assess population admixture and ethnic backgrounds. Duffy polymorphisms are characterized for African populations, therefore identification of the $F y B^{E S}$ variant in non-African populations is likely to be the result of admixture of the African-American genetic background $[6,11,35]$. The genotype and allele frequency distributions recorded for four analysed SNPs in two population groups, the Shagia and Manasir tribes, are presented in Table 1. Genotype distributions were consistent with the HardyWeinberg expectations for T-33 C and G125A SNPs only (Table 1).

Pair-wise linkage disequilibrium (LD) between T-33 C and G125A polymorphisms was calculated using the normalized disequilibrium coefficient ( $\left.\mathrm{D}^{\prime}\right)$ and was equal $0.51\left(\right.$ Corr $\left.=0,31, \mathrm{p}=5 \mathrm{e}^{-10}\right)$.

The analysis of allelic and genotype frequency in the T$33 \mathrm{C}$ polymorphisms demonstrated a significant dominance of the $C$ allele and $C C$ genotype $(\mathrm{OR}=0.53$ [0.32$0.88]$ ) in both tribes. Moreover, the frequency of allele $C$ was significantly higher in Shagia than Manasir ( $p=$ 0.02). The prevalence of $C C$ genotype in the Shagia and the Mansir was respectively $77 \%$ and $62.6 \%$. These results are in agreement with previous reports showing that the $-33 \mathrm{C}$ allele was present in $79 \%$ of South African blacks [25] and 78.3\% of African-American populations [30]. Allelic and genotype frequencies in other analysed SNPs, i.e. G125A and C5411T were similar in both tribes and align with the data representative for Africans. The study showed that $A A$ homozygotes are dominant in G125A polymorphisms among the members of Shagia and Manasir tribes (88.9\% and $86.8 \%$, respectively). With regard to G298A polymorphisms the genotype frequencies were different between the tribes $(p=0,002)$. It is worthy of note that no single $A A$ homozygote was found in the examined groups although the presence of the $A A$ genotype in sub-Saharan Africa was reported (0.99\%). According to HapMap the GA heterozygotes among European populations predominate in G298A polymorphisms. On the other hand, the GG homozygotes, which were found in both analysed tribes, are typical of the Euro-Brazilians, Afro-Brazilians, Asian-Brazilians and Amerindians (Cayapo/Yanomama) [31].

The haplotype frequency was designated on the basis of two SNPs: T-33 C and G125A (Table 2). Duffy-negative blood groups were identified in $83 \%$ of the Shagia and $77 \%$ of Manasir, what is consistent with the epidemiological data which demonstrated that 70 to $80 \%$ of people in north-eastern Sudan had Duffy-negative blood group [36]. The frequency of the obtained haplotypes (Table 2) was compared to SNP genotypic data from HapMap Data Rel 27 and the similarity was observed between the examined groups and the population of African ancestry in the Southwest USA (ASW: CA $=0.81 ; \mathrm{TA}=0.07$; $\mathrm{TG}=0.12$ ).

In the presented study, determination of Duffy genotype and phenotype was based on the T-33 C (GATA polymorphism) and G125A SNPs (Table 3) [10-12,15]. Twenty combinations of genotypes for the Shagia and Manasir tribes were examined (Table 3 ). There was a statistically significant difference in frequency of one of the genotype combinations, i.e. $C C / A A / G G / C T\left(F Y^{*} B^{E S} / F Y^{*} B^{E S}\right)(p=$ 0.001 ) which occurred in $45.87 \%$ of the Shagia tribe but in only $6.59 \%$ of the Manasir tribe.

For homozygotes with the inactive-GATA site and G125A genotypes: $F Y^{*} B / F Y^{*} B$ or $F Y^{*} A / F Y^{*} B$, the deduced genotypes were $F Y^{*} B^{E S} / F Y^{*} B E S$ and $F Y^{*} A^{E S} / F Y^{*} B^{E S}$, respectively and the phenotype was Fy(a-, b-).

The genotype and phenotype were consistent with G125A when the individuals were wild-type GATA site homozygous. According to Woolley et al [37] and Yazdanbakhsh et al [10], the mutation in the GATA box is associated with the functional allele $F Y^{* *} B[10,37]$. However, Zimmerman et al [15] suggest that the T-33 C polymorphism affect $F y$ expression on the $F Y^{*} A$ and $F Y^{* * B}$ alleles in a similar manner [15]. Therefore, in the case when an individual was characterized by heterozygous GATA site (GATA+/-) and the genotype $F Y^{* *} A / F Y^{*} B$ (for G125A), both types of genotypes, i.e. $F Y^{*} A^{E S} / F Y^{*} B$ or $F Y^{*} A / F Y^{*} B^{E S}$ (phenotype Fy(a+, b-) or Fy(a-, b+)) can be predicted. Similarly, for $F Y^{*} A / F Y^{*} A$ homozygous, two deduced genotypes such as $F Y^{*} A^{E S} / F Y^{*} A$ or $F Y^{*} A / F Y^{*} A^{E S}$ (phenotype $\mathrm{Fy}(\mathrm{a}+, \mathrm{b}-)$ ) were assigned. Moreover, Zimmerman et al [15] imply that the $F Y^{*} A^{E S}$ allele is a new allele 
Table 1 Allele and genotype association results for Duffy in the Shagia and Manassir

\begin{tabular}{|c|c|c|c|c|c|c|c|}
\hline \multirow[t]{2}{*}{ SNP } & \multirow[t]{2}{*}{ Allele/genotype } & \multicolumn{2}{|c|}{ Allele frequency } & \multirow[t]{2}{*}{ OR (95\% CI) } & \multirow[t]{2}{*}{$\begin{array}{l}\text { Fisher's Exact } \\
\text { P-Value }\end{array}$} & \multicolumn{2}{|c|}{$\begin{array}{c}\text { Hardy-Weinberg's Exact } \\
P \text {-Value }\end{array}$} \\
\hline & & Shagia, n (\%) & Manasir, n (\%) & & & Shagia & Manasir \\
\hline \multirow[t]{4}{*}{$\mathrm{T}-33 \mathrm{C}$} & $T / C$ & $33 / 219(13.1 / 86,9)$ & $40 / 142(22 / 78)$ & $0.53(0.32-0 ., 88)$ & 0.02 & & \\
\hline & $T T$ & $4(3.2)$ & $6(6.6)$ & & 0.01 & 0.22 & 0.36 \\
\hline & $T C$ & $25(19.8)$ & $28(30.8)$ & & & & \\
\hline & $C C$ & $97(77)$ & $57(62.6)$ & & & & \\
\hline \multirow[t]{4}{*}{ G125A } & $G / A$ & $235 / 17(93,2 / 6,8)$ & $169 / 13(92.9 / 7.1)$ & $1.06(0.5-2.25)$ & $>0.9$ & & \\
\hline & GG & $3(2.4)$ & $1(1.1)$ & & 0.58 & 0.01 & 0.37 \\
\hline & $G A$ & $11(8.7)$ & $11(12.1)$ & & & & \\
\hline & $A A$ & $112(88.9)$ & $79(86.8)$ & & & & \\
\hline \multirow[t]{4}{*}{ G298A } & $G / A$ & $162 / 90(64,3 / 35,7)$ & $101 / 81(55.5 / 44.5)$ & $1.44(0.97-2.13)$ & 0.07 & & \\
\hline & GG & $36(28.6)$ & $10(11)$ & & 0.002 & $<0.00$ & $<0.00$ \\
\hline & $G A$ & $90(71.4)$ & $81(89)$ & & & & \\
\hline & $A A$ & $0(0)$ & $0(0)$ & & & & \\
\hline \multirow[t]{4}{*}{ C5411T } & $\mathrm{C} / T$ & $136 / 116(54 / 46)$ & $95 / 87(52.2 / 47.8)$ & $1.07(0.73-1.57)$ & 0.8 & & \\
\hline & $C C$ & $10(7.9)$ & $4(4.4)$ & & 0.46 & $<0.00$ & $<0.00$ \\
\hline & $C T$ & $116(92.1)$ & $87(95.6)$ & & & & \\
\hline & $T T$ & $0(0)$ & $0(0)$ & & & & \\
\hline
\end{tabular}

independent of African origin, as opposed to the $F Y^{*} B^{E S}$ alleles predominating in African and African-American populations. The $F Y^{*} B^{E S}$ allele was also the most numerous identified in the Shagia $51(+/-2.5)$ and in the Manarsir $32.5(+/-4)$.

The most remarkable finding in the presented study is the identification of occurrence of $F Y^{*} A^{E S}$ allele in the analysed tribes, which is consistent with the anthropological data and may suggest free flow of the genetic material in the analysed populations, i.e. admixture of non-African population in some periods. The presence of individuals with the $F Y^{*} A / F Y^{*} A$ genotype in the Shagia tribe, who are not found in the Manasir population (Table 3), indicates more numerous re-combinations among the Shagia than the Manasir people. Interestingly, admixture of non-African population in this geographically isolated tribe was additionally confirmed by the authors in previous studies [38]. Furthermore, the genetic structure of the Shagia population differs significantly from the Manasir population, where there was a free flow of genetic material as the Manasir tribe inhabits the region of the Fourth Nile
Cataract with other populations such as the Beniamer, Ababda, Foraui and Kesinger tribes. It is worth noting that the $F Y^{*} A^{E S}$ allele is not observed in a more ethnically diverse populations, for example, in some tribes from Papua New Guinea (i.e. South Wosera) [15].

Indigenous Africans are characterized by high levels of genetic diversity within and between populations [26]. Also, the mtDNA evidence has suggested that southern Africa and the remainder of sub-Saharan Africa were regionally differentiated [39]. It would be interesting to continue research using more powerful bio-markers, such as Y-chromosome and/or mtDNA. Unfortunately, both the nature of the research conducted by this study and the small amount and unique character of the collected material make it impossible.

\section{Conclusion}

The present study demonstrated, by all accounts for the first time, Duffy-negative genotype combination i.e. $F Y^{*} B^{E S} / F Y^{*} A^{E S}$. Moreover, the results suggest the admixture of non-African genetic materials in both tribes.

Table 2 Two-locus (T-33 C, G125A) haplotype analysis using HAPLO.SCORE, overall $p=0,08$

\begin{tabular}{ccccccc}
\hline Haplotype & \multicolumn{2}{c}{ Haplotype frequency } & Overall haplotype frequency & HAP-Score & $\begin{array}{c}\text { Overall } \\
\text { P-Value }\end{array}$ \\
\cline { 2 - 5 } & Shagia & Monassir & & $-1,59$ & 0,11 \\
\hline CA & 0,83 & 0,77 & 0,80 & $-1,26$ & 1,36 & 0,21 \\
\hline CG & 0,04 & 0,01 & 0,03 & 0,17 \\
\hline TG & 0,29 & 0,06 & 0,04 & 1,85 & 0,06 \\
\hline TA & 0,10 & 0,16 & & 0,13 & 0 \\
\hline
\end{tabular}


Table 3 Frequency of T-33 C, G125A, G298A and C5411T genotype combinations

\begin{tabular}{|c|c|c|c|c|c|c|c|c|c|c|}
\hline & enotype & combina & ations & Shagia, & Manasir, & & GATA genotype & Deduced genotype & Predicted & Predicted \\
\hline $\begin{array}{l}\mathrm{T}- \\
33 \mathrm{C}\end{array}$ & G125A & G298A & C5411T & & & & & & & \\
\hline$\pi$ & $A A$ & GA & $C T$ & $1(0,8)$ & $4(4,4)$ & 0,16 & GATA+ & $F Y^{*} B / F Y^{*} B$ & $F Y^{*} B / F Y^{*} B$ & Fy $(a-, b+)$ \\
\hline$\pi$ & $A A$ & GG & $C T$ & $1(0,8)$ & $0(0,0)$ & $\geq 0,99$ & GATA+ & $F Y^{*} B / F Y^{*} B$ & $F Y^{*} B / F Y^{*} B$ & Fy $(a-, b+)$ \\
\hline$\pi$ & GA & GG & $C T$ & $1(0,8)$ & $0(0,0)$ & $\geq 0,99$ & GATA+ & $F Y^{*} A / F Y^{*} B$ & $F Y^{*} A / F Y^{*} B$ & Fy $(a+, b+)$ \\
\hline$\pi$ & GA & GA & $C T$ & $0(0,0)$ & $2(2,2)$ & 0,17 & GATA+ & $F Y^{*} A / F Y^{*} B$ & $F Y^{*} A / F Y^{*} B$ & Fy $(a+, b+)$ \\
\hline$\pi$ & GG & GG & $C T$ & $1(0,8)$ & $0(0,0)$ & $\geq 0,99$ & GATA+ & $F Y^{*} A / F Y^{*} A$ & $F Y^{*} A / F Y^{*} A$ & Fy $(a+, b-)$ \\
\hline TC & $A A$ & GG & $C C$ & $1(0,8)$ & $0(0,0)$ & $\geq 0,99$ & GATA+/- & $F Y^{*} B / F Y^{*} B$ & $F Y^{*} B / F Y^{*} B$ & Fy $(a-, b+)$ \\
\hline TC & $A A$ & $G A$ & $C T$ & $17(13,5)$ & $16(17,6)$ & 0,45 & GATA+/- & $F Y^{*} B / F Y^{*} B$ & $F Y^{*} B / F Y^{*} B$ & Fy $(a-, b+)$ \\
\hline TC & $A A$ & GG & $C T$ & $2(1,6)$ & $3(3,3)$ & 0,65 & GATA+/- & $F Y^{*} B / F Y^{*} B$ & $F Y^{*} B / F Y^{*} B$ & Fy $(a-, b+)$ \\
\hline$T C$ & $G A$ & $G A$ & $C T$ & $4(3,2)$ & $7(7,7)$ & 0,21 & GATA+/- & $F Y^{*} A / F Y^{*} B$ & $\begin{array}{c}F Y^{*} A^{E S} / F Y^{*} B \text { or } \\
F Y^{*} A / F Y^{*} B^{E S}\end{array}$ & $\begin{array}{c}\text { Fy }(a+, b-) \\
\text { or } \\
\text { Fy }(a-, b+)\end{array}$ \\
\hline$T C$ & $G A$ & $G G$ & $C T$ & $1(0,8)$ & $1(1,1)$ & $\geq 0,99$ & GATA+/- & $F Y^{*} A / F Y^{*} B$ & $\begin{array}{c}F Y^{*} A^{E S} / F Y^{*} B \text { or } \\
F Y^{*} A / F Y^{*} B^{E S}\end{array}$ & $\begin{array}{c}\text { Fy }(a+, b-) \\
\text { or } \\
\text { Fy }(a-, b+)\end{array}$ \\
\hline$T C$ & GG & $G A$ & $C T$ & $0(0,0)$ & $1(1,1)$ & 0,41 & GATA+/- & $F Y^{*} A / F Y^{*} A$ & $\begin{array}{c}F Y^{*} A F Y^{*} A^{E S} \text { or } \\
F Y^{*} A^{E S} / F Y^{*} A\end{array}$ & Fy $(a+, b-)$ \\
\hline$C C$ & $A A$ & GG & $C C$ & $4(3,2)$ & $0(0,0)$ & 0,14 & GATA- & $F Y^{*} B / F Y^{*} B$ & $F Y^{*} B^{E S} / F Y^{*} B^{E S}$ & Fy $(a-, b-)$ \\
\hline$C C$ & $A A$ & GA & $C C$ & $2(1,6)$ & $4(4,4)$ & 0,24 & GATA- & $F Y^{*} B / F Y^{*} B$ & $F Y^{*} B^{E S} / F Y^{*} B^{E S}$ & Fy $(a-, b-)$ \\
\hline$C C$ & $A A$ & GG & $C T$ & $20(45,9)$ & $6(6,6)$ & $\leq 0,001$ & GATA- & $F Y^{*} B / F Y^{*} B$ & $F Y^{*} B^{E S} / F Y^{*} B^{E S}$ & Fy $(a-, b-)$ \\
\hline$C C$ & $A A$ & $G A$ & $C T$ & $64(50,8)$ & $46(50,6)$ & $\geq 0,99$ & GATA- & $F Y^{*} B / F Y^{*} B$ & $F Y^{*} B^{E S} / F Y^{*} B^{E S}$ & Fy $(a-$, b-) \\
\hline$\overline{C C}$ & $G A$ & GG & $C C$ & $2(1,6)$ & $0(0,0)$ & 0,51 & GATA- & $F Y^{*} A / F Y^{*} B$ & $F Y^{*} A^{E S} / F Y^{*} B^{E S}$ & Fy (a-, b-) \\
\hline$C C$ & $G A$ & GG & $C T$ & $2(1,6)$ & $0(0,0)$ & 0,51 & GATA- & $F Y^{*} A / F Y^{*} B$ & $F Y^{*} A^{E S} / F Y^{*} B^{E S}$ & Fy $(a-, b-)$ \\
\hline$C C$ & $G A$ & GA & $C T$ & $1(0,8)$ & $1(1,1)$ & $\geq 0,99$ & GATA- & $F Y^{*} A / F Y^{*} B$ & $F Y^{*} A^{E S} / F Y^{*} B^{E S}$ & Fy (a-, b-) \\
\hline$C C$ & GG & GG & $C C$ & $1(0,8)$ & $0(0,0)$ & $\geq 0,99$ & GATA- & $F Y^{*} A / F Y^{*} B$ & $F Y^{*} A^{E S} / F Y^{*} B^{E S}$ & Fy $(a-, b-)$ \\
\hline$\overline{C C}$ & GG & $G A$ & $C T$ & $1(0,8)$ & $0(0,0)$ & $\geq 0,99$ & GATA- & $F Y^{*} A / F Y^{*} B$ & $F Y^{*} A^{E S} / F Y^{*} B^{E S}$ & Fy (a-, b-) \\
\hline
\end{tabular}

In the case of the Manasir population, it is in accordance with the collected ethnographic data, while with regard to the isolated Shagia tribe, which has not been anthropologically and genetically described so far, it is a useful trace for explaining the history of this population. The $F Y^{*} A^{E S}$ allele, identified in both tribes, is not likely to be directly related to the exposure of a human genome to $P$. vivax but rather may be a consequence of admixture of the non-African genetic background.

\section{Acknowledgements}

The authors wish to thank Henryk Paner, chief of Archaeological Museum in Gdansk, for the opportunity to conduct research in the Fourth Cataract of the Nile Basin and also Mahmoud el Tayeb and the entire Shagia tribe for the support and kindness. In addition, we would like to express our gratitude to the reviewer of this paper for valuable comments. This study was supported by a grant from the Ministry of Science and Higher Education, Republic of Poland (No. N N404 140837).

\section{Author details}

${ }^{1}$ Medical Biology Laboratory, Pomeranian Medical University, Powstancow Wlkp 72, 70-111 Szczecin, Poland. ${ }^{2}$ Independent Laboratory of Disaster Medicine, Pomeranian Medical University, Rybacka 1, 70-204 Szczecin, Poland. ${ }^{3}$ Department of Biochemistry and Human Nutrition, Pomeranian
Medical University, Broniewskiego 24, 71-460 Szczecin, Poland. ${ }^{4}$ Department of Clinical and Molecular Biochemistry, Pomeranian Medical University, Powstancow WIkp 72, 70-111 Szczecin, Poland. ${ }^{5}$ Department of Forensic Medicine, Pomeranian Medical University, Powstancow Wlkp 72, 70-111 Szczecin, Poland. ${ }^{6}$ Chair and Clinic of Infectious Diseases, Pomeranian Medical University, Arkońska 4, 71-455 Szczecin, Poland.

\section{Authors' contributions}

AKP and AC designed and implemented the survey and wrote the article. $\mathrm{OMK}$ and $\mathrm{MP}^{5}$ were responsible for selection of the patients and collect of the samples. AKP, AD, MP ${ }^{6}$ were responsible for genotyping. AKP and MK conducted the data analysis. All authors read and approved the final manuscript.

\section{Competing interests}

The authors declare that they have no competing interests.

Received: 30 November 2011 Accepted: 17 April 2012 Published: 17 April 2012

\section{References}

1. Tishkoff SA, Williams SM: Genetic analysis of African populations: human evolution and complex disease. Nat Rev Genet 2002, 3:611-621.

2. Lambert CA, Tishkoff SA: Genetic structure in African populations: implications for human demographic history. Cold Spring Harb Symp Quant Biol 2009, 74:395-402. 
3. Albuquerque SR, Cavalcante FO, Sanguino EC, Tezza L, Chacon F, Castilho L, et al: FY polymorphisms and vivax malaria in inhabitants of Amazonas State, Brazil. Parasitol Res 2010, 106:1049-1053.

4. Donahue RP, Bias WB, Renwick JH, McKusick VA: Probable assignment of the Duffy blood group locus to chromosome 1 in man. Proc Natl Acad Sci USA 1968, 61:949-955.

5. Tournamille C, Le Van KC, Gane P, Cartron JP, Colin Y: Molecular basis and PCR-DNA typing of the Fya/fyb blood group polymorphism. Hum Genet 1995, 95:407-410.

6. Parasol N, Reid M, Rios M, Castilho L, Harari I, Kosower NS: A novel mutation in the coding sequence of the $\mathrm{FY}^{*} \mathrm{~B}$ allele of the Duffy chemokine receptor gene is associated with an altered erythrocyte phenotype. Blood 1998, 92:2237-2243.

7. Hadley TJ, Peiper SC: From malaria to chemokine receptor: the emerging physiologic role of the Duffy blood group antigen. Blood 1997, 89:3077-3091.

8. Pogo AO, Chaudhuri A: The Duffy protein: a malarial and chemokine receptor. Semin Hematol 2000, 37:122-129.

9. Schnabel RB, Baumert J, Barbalic M, Dupuis J, Ellinor PT, Durda P, Dehghan A, Bis JC, Illig T, Morrison AC, Jenny NS, Keaney JF Jr, Gieger C, Tilley C, Yamamoto JF, Khuseyinova N, Heiss G, Doyle M, Blankenberg S, Herder C, Walston JD, Zhu Y, Vasan RS, Klopp N, Boerwinkle E, Larson MG, Psaty BM, Peters A, Ballantyne CM, Witteman JC, Hoogeveen RC, Benjamin EJ, Koenig W, Tracy RP: Duffy antigen receptor for chemokines (Darc) polymorphism regulates circulating concentrations of monocyte chemoattractant protein-1 and other inflammatory mediators. Blood 2010, 115:5289-5299.

10. Yazdanbakhsh K, Rios M, Storry JR, Kosower N, Parasol N, Chaudhuri A, Reid ME: Molecular mechanisms that lead to reduced expression of duffy antigens. Transfusion 2000, 40:310-320.

11. Castilho L, Rios M, Pellegrino J Jr, Saad ST, Costa FF, Reid ME: A novel FY allele in Brazilians. Vox Sang 2004, 87:190-195.

12. Cavasini CE, de Mattos LC, Couto AA, Couto VS, Gollino Y, Moretti L, Bonini-Domingos CR, Rossit AR, Castilho L, Machado RL: Duffy blood group gene polymorphisms among malaria vivax patients in four areas of the Brazilian Amazon region. Malar J 2007, 6:167.

13. Iwamoto S, Li J, Sugimoto N, Okuda H, Kajii E: Characterization of the Duffy gene promoter: evidence for tissue-specific abolishment of expression in Fy(a-b-) of black individuals. Biochem Biophys Res Commun 1996, 222:852-859.

14. Tournamille C, Colin Y, Cartron JP, Le Van KC: Disruption of a GATA motif in the Duffy gene promoter abolishes erythroid gene expression in Duffy-negative individuals. Nat Genet 1995, 10:224-228.

15. Zimmerman PA, Woolley I, Masinde GL, Miller SM, McNamara DT, Hazlett F, Mgone CS, Alpers MP, Genton B, Boatin BA, Kazura JW: Emergence of FY*A (null) in a Plasmodium viva-endemic region of Papua New Guinea. Proc Natl Acad Sci USA 1999, 96:13973-13977.

16. Vergara C, Tsai YJ, Grant AV, Rafaels N, Gao L, Hand T, Stockton M, Campbell M, Mercado D, Faruque M, Dunston G, Beaty TH, Oliveira RR, Ponte EV, Cruz AA, Carvalho E, Araujo MI, Watson H, Schleimer RP, Caraballo L, Nickel RG, Mathias RA, Barnes KC: Gene encoding Duffy antigen/receptor for chemokines is associated with asthma and IgE in three populations. Am J Respir Crit Care Med 2008, 178:1017-1022.

17. Howes RE, Patil AP, Piel FB, Nyangiri OA, Kabaria CW, Gething PW, Zimmerman PA, Barnadas C, Beall CM, Gebremedhin A, Ménard D, Williams TN, Weatherall DJ, Hay SI: The global distribution of the Duffy blood group. Nat Commun 2011, 2:266.

18. Maestre A, Muskus C, Duque V, Agudelo O, Liu P, Takagi A, Takagi A, Ntumngia FB, Adams JH, Sim KL, Hoffman SL, Corradin G, Velez ID, Wang R: Acquired antibody responses against Plasmodium viva infection vary with host genotype for duffy antigen receptor for chemokines (DARC). PLoS One 2010, 5:e11437.

19. Hamblin MT, Di RA: Detection of the signature of natural selection in humans: evidence from the Duffy blood group locus. Am J Hum Genet 2000, 66:1669-1679.

20. Tournamille C, Le Van KC, Gane P, Le Pennec PY, Roubinet F, Babinet J, Cartron JP, Colin Y: Arg89Cys substitution results in very low membrane expression of the Duffy antigen/receptor for chemokines in Fy(x) individuals. Blood 1998, 92:2147-2156.

21. Abdelaal MA, Anyaegbu CC, al Sobhi EM, al Baz NM, Hodan K: Blood group phenotype distribution in Saudi Arabs. Afr J Med Med Sci 1999, 28:133-135.
22. Sandler SG, Kravitz C, Sharon R, Hermoni D, Ezekiel E, Cohen T: The Duffy blood group system in Israeli Jews and Arabs. Vox Sang 1979, 37:41-46.

23. Kobyliansky E, Micle S, Goldschmidt-Nathan M, Arensburg B, Nathan H: Duffy, Kell and P blood group systems in some Jewish populations of Israel. Acta Anthropogenet 1980, 4:173-179.

24. Chiaroni J, Touinssi M, Frassati C, Degioanni A, Gibert M, Reviron D, Mercier P, Boëtsch G: Genetic characterization of the population of Grande Comore Island (Njazidja) according to major blood groups. Hum Biol 2004, 76:527-541.

25. Nickel RG, Willadsen SA, Freidhoff LR, Huang SK, Caraballo L, Naidu RP, Levett P, Blumenthal M, Banks-Schlegel S, Bleecker E, Beaty T, Ober C, Barnes KC: Determination of Duffy genotypes in three populations of African descent using PCR and sequence-specific oligonucleotides. Hum Immunol 1999, 60:738-742.

26. Campbell MC, Tishkoff SA: African genetic diversity: implications for human demographic history, modern human origins, and complex disease mapping. Annu Rev Genomics Hum Genet 2008, 9:403-433.

27. Sirugo G, Hennig BJ, Adeyemo AA, Matimba A, Newport MJ, Ibrahim ME, Ryckman KK, Tacconelli A, Mariani-Costantini R, Novelli G, Soodyall H, Rotimi CN, Ramesar RS, Tishkoff SA, Williams SM: Genetic studies of African populations: an overview on disease susceptibility and response to vaccines and therapeutics. Hum Genet 2008, 123:557-598.

28. Tishkoff SA, Reed FA, Friedlaender FR, Ehret $C$, Ranciaro A, Froment A, Hirbo JB, Awomoyi AA, Bodo JM, Doumbo O, Ibrahim M, Juma AT, Kotze MJ, Lema G, Moore JH, Mortensen H, Nyambo TB, Omar SA, Powell K, Pretorius GS, Smith MW, Thera MA, Wambebe C, Weber JL, Williams SM: The genetic structure and history of Africans and African Americans. Science 2009, 324:1035-1044.

29. Phillips C, Salas A, Sanchez JJ, Fondevila M, Gomez-Tato A, Alvarez-Dios J, et al: Inferring ancestral origin using a single multiplex assay of ancestryinformative marker SNPs. Forensic Sci Int Genet 2007, 1:273-280.

30. Olsson ML, Hansson C, Avent ND, Akesson IE, Green CA, Daniels GL: A clinically applicable method for determining the three major alleles at the Duffy (FY) blood group locus using polymerase chain reaction with allele-specific primers. Transfusion 1998, 38:168-173.

31. Estalote AC, Proto-Siqueira R, Silva WA Jr, Zago MA, Palatnik M: The mutation G298A- > Ala100Thr on the coding sequence of the Duffy antigen/chemokine receptor gene in non-caucasian Brazilians. Genet Mol Res 2005, 4:166-173.

32. Gassner C, Kraus RL, Dovc T, Kilga-Nogler S, Utz I, Mueller TH, Schunter F, Schoenitzer D: Fyx is associated with two missense point mutations in its gene and can be detected by PCR-SSP. Immunohematology 2000, 16:61-67.

33. Schmid P, Ravenell KR, Sheldon SL, Flegel WA: DARC alleles and Duffy phenotypes in African Americans. Transfusion 2011, Published on line 14 Nov.

34. Schaid DJ, Rowland CM, Tines DE, Jacobson RM, Poland GA: Score tests for association between traits and haplotypes when linkage phase is ambiguous. Am J Hum Genet 2002, 70:425-434.

35. Reed FA, Tishkoff SA: African human diversity, origins and migrations. Curr Opin Genet Dev 2006, 16:597-605.

36. Rosenberg R: Plasmodium viva in Africa: hidden in plain sight? Trends Parasitol 2007, 23:193-196.

37. Woolley IJ, Hotmire KA, Sramkoski RM, Zimmerman PA, Kazura JW: Differential expression of the duffy antigen receptor for chemokines according to RBC age and FY genotype. Transfusion 2000, 40:949-953.

38. Kempinska-Podhorodecka AD, Knap O, Parczewski M, Bińczak-Kuleta A, Parafiniuk M: Report on the D32 CCR5 variant inthe Sudanese Shagia tribe. Anthropol Rev 2008, 71:71-76.

39. Henn BM, Gignoux CR, Jobin M, Granka JM, Macpherson JM, Kidd JM, Rodríguez-Botigué L, Ramachandran S, Hon L, Brisbin A, Lin AA, Underhill PA, Comas D, Kidd KK, Norman PJ, Parham P, Bustamante CD, Mountain JL, Feldman MW: Hunter-gatherer genomic diversity suggests a southern African origin for modern humans. Proc Natl Acad Sci USA 2011, 108:5154-5162.

doi:10.1186/1475-2875-11-115

Cite this article as: Kempińska-Podhorodecka et al:: Analysis for genotyping Duffy blood group in inhabitants of Sudan, the Fourth Cataract of the Nile. Malaria Journal 2012 11:115. 